\title{
Perceptions of Environmental Accounting in the Jordanian Pharmaceutical Industries (Applications and Disclosure)
}

\author{
Munther Al-Nimer \\ ${ }^{1}$ Accounting, Applied Science University, Jordan \\ Correspondence: Munther Al-Nimer, Accounting Applied Science University, Jordan. E-mail: \\ muntheralnimer@yahoo.com
}

Received: November 12, 2014

Accepted: November 18, 2014

Online Published: January 20, 2015

doi:10.5539/ijbm.v10n2p73

URL: http://dx.doi.org/10.5539/ijbm.v10n2p73

\begin{abstract}
This study aims to identify the extent of awareness on environmental responsibilities in the Jordanian Pharmaceutical industries, identifying how the Pharmaceutical industries in Jordan apply the environmental accounting policy in their factories, Measure the level of commitment of Jordanian Pharmaceutical industries with the Jordanian Environmental Protection Act No. 52 of 2006. Finally, determine the level of environmental accounting disclosure in the Jordanian Pharmaceutical industries. To attain these objectives, a combination of research methods have been conducted, namely, questionnaire and content analysis; 10 valid questionnaires were returned, giving a $62 \%$ response rate, followed by 10 content analysis for annual financial statements. descriptive analysis and statistical analysis were used to analyze the responses.

The findings reported that Jordanian Pharmaceutical industries utilize high technology in accounting departments, $60 \%$ of them utilize environmental information system (EIS) in the company. The need by the management of the organization was the main cause of measurement of environmental impact of their activities followed by obligatory causes mainly the Jordanian Environment Protection Act No. 52 of 2006. In the same aspect the study revealed that the industries committed to Environment accounting by both internal policies and governmental regulations. The study indicated that the availability of electronic accounting system, internal environmental control units, and educational programs and courses were main essential requirements to keep pace with the development through environmental accounting functions.

Furthermore, the study indicated that industries were concerned in the disposal of industrial waste which separates them from others, by the efficiency and effectiveness of the organizations activities through environmental accounting, alongside with the calculation of production cost and determining prices. Finally, the study revealed that the majority of the industries disclose their environmental accounting information in their financial statements.
\end{abstract}

Keywords: environmental accounting, pharmaceutical industries, environmental disclosure

\section{Introduction}

Recently the global debate emphasized on environmental Problems particularly the unawareness of environmental consequences : such as global warming, and pollution of all kind: such as water, air, marine, noise, and light etc ,these are current problems in the present century in which the development of developing countries may be held responsible. As a result many studies were conducted to examine the effect of environmental matters (see, for example, Beattie, 2014; Cho \& Patten, 2013; Deegan et al., 2000; Ditz \& Ranganathan, 1997; Gray \& Bebbington, 2001; Jasch, 2003 and others). Therefore, in the 21st century there is a consensus for an urgent need of protecting our environment, because the environment is important for the survival of human beings.

"Only when the last blade of grass is gone, only when the last tree is cut down, only when the last fish is caught, only when the last river is poisoned, will man realize they cannot eat money". Chief Seattle, to the US Congress, 1854, quoted in ACCA (2003).

Consequently, research concerning the environmental problems has been rapidly evolving, environmental accounting, environmental risk assessments, and environmental accounting disclosure, are studied in order to meet an urgent response to the environmental problems, particularly firms that effect the environment by the 
activities emphasis on business environmental associations (see, for example, Soobaroyen \& Ntim, 2013; Adams et al., 1998; Bansal \& Howa, 1997; Deegan et al., 2000; Frost \& Wilmshurst, 2000; Gamble et al., 1996; Burritt \& Saka, 2006).

Environmental accounting is an important tool for understanding the role played by the natural environment in the economy. As a result, Environmental accounts provide data which highlight both the contribution of natural resources to economic well-beings and the cost imposed by pollution or resource degradation of the Environment which is a precious gift of nature. Environment means everything that surrounds us, the environment is an essential factor for the survival of human beings (Qureshi et al., 2012).

Baba, (2012) indicated that there is a variety of meanings regarding environmental accounting according to the contexts, they call it Green accounting (this term was used since 1980) which was defined as a method of measuring (in economic terms) the performance of the organizations in relation to the environment and environmental accounting are taken to mean in the identification and reporting of the environments specific cost, such as liability cost or waste disposal cost. For the purposes of this analysis a much more general definition is used. "Environmental accounting" is more than accounting for environmental benefits and cost. It is accounting for any cost and benefit that arises from changes in a firm's product or processe, where the change also has impact on the environment (Boyd, 1998).

Subsequently, several studies were conducted regarding environmental issues especially environmental accounting, Jordan as a developing country has drawn the attention to environmental problems that is seen by placing the Jordanian Environmental Protection Act No. 52 of 2006. (Ministry of Environment, 2014).

Therefore, the current study will identify the level of awareness and implementation of environmental issues on the Jordanian Pharmaceutical sector. Furthermore, the study will attempt to identify the level of environmental accounting and the disclosure of Jordanian Pharmaceutical industries.

\subsection{Study Objectives}

This study aims to identify the level of awareness of the accounting departments within the Jordanian Pharmaceutical industries of environmental accounting by focusing on the following objectives:

- Identify the extent of awareness on environmental responsibilities in the Jordanian Pharmaceutical industries.

- Identify how the Pharmaceutical industries in Jordan apply the environmental accounting rules.

- Measure the level of commitment of Jordanian Pharmaceutical industries with the Jordanian Environmental Protection Act No. 52 of 2006 .

- Determine the level of environmental accounting and disclosure in the Jordanian Pharmaceutical industries.

\subsection{Research Problem}

The problem with this study, is the extent of which the Jordanian Pharmaceutical industry administration is committed to the environmental responsibilities imposed by legal law (such as the Environmental Protection Act 2006 Jordanian) or committed of the ethical responsibilities.

This problem can be formulated in the following set of questions :

- Do financial departments in industries cope with the developments in the law and regulations issued by the government.

- Do industries finance departments that take into account environmental responsibilities in their policies and strategies?

- Do Jordanian Pharmaceutical industries disclose the environmental responsibilities in their financial statements?

\section{Literature Review}

Cho and Roberts (2010) applied content analysis to the corporate websites environmental disclosure of samples of firms and found that worse environmental performers provide more extensive disclosure in terms of content and website presentation. Hence, this highlighted and affirmed the purported de-coupling of actual firms environmental performance (i.e. back stage reality) from the firms" website of environmental disclosures (i.e. front stage portrayal of a proper, socially acceptable environmental posture).

Saymeh and Al Shoubaki (2013) indicated that accounting ideology is becoming highly concerned of the environmental responsibilities. They emphasized on the importance of environmental accounting principles and 
all enterprises and recommended the need of environmental commitment in any project in terms of its contribution to its environmental responsibilities. This study concluded that the Jordanian general was committed towards environmental accounting and they keep pace of the development of this field.

Patten (2002) examined the relation between a US samples 1990 annual report environmental disclosures and their environmental performance. The study indicated that controlling the firm sizes and industry classifications aroused a significant negative relation between performance and disclosure for the sample firms during that period. Moreover, the disclosure level of firms from non-environmentally sensitive industries seemed more affected by the toxic release levels than was the disclosure of firms from environmentally sensitive industries.

Contrafat to and Burns (2013), their study highlighted the importance of management accounting in facilitating and shaping the cumulative path of social and environmental accounting and reporting (SEAR) practices by focusing on the interrelationship between organizational change and SEAR practices. As a result the study extended the understanding of SEAR practices as cumulative process over time, an awareness of the potential limits to such developments in profit-seeking organizations, and stresses a need to be circumspect when involving management accounting and pay attention to the uncritical reliance on conventional management accounting tools.

A study conducted by Blioumis, V., et al, (2012) in order to examine if environmental management accounting, and especially Environmental Cost Accounting which could support both the augmentation of environmental nonprofit/nongovernmental sector's accountability, and the provision of meaningful results for policy decision making. The study indicated that the existing Environmental Management Accounting tools can partly address the several dimensions of their operation and additional accounting regimes were been needed. Nevertheless, these tools can be a useful starting point.

Jones (2011) declared that social and environmental reports are growing in a study that aimed to investigate graph usage in social and environmental reports. The results show that the graphs are widely used. Key managerial preferences are shown to be air pollution, waste output, energy usage and employees. High profile industrial sectors, particularly the extractive industries, used graphs the most. There was clear evidence of impression management in graph usage. In terms of trends selected and in the distortion of those trends, there was an overwhelming portrayal of good rather than bad news. Companies in high impact industries tended to present relatively more good news than bad news in graphs and distort graphs relatively more favourable than those in low impact companies.

\section{Research Methodology}

With reliance on the Ministry of Industry and Trade records at March 2014, the Pharmaceutical and Medical Industries sector consisted of 10 industries, therefore the current study will include the whole population in the study.

To ensure conformity with the objectives of the research, the current research employed the quantitative approach and the qualitative approach at the same time which is called the multi-method approach by applying a questionnaire analysis and content analysis (Saunders, 2007).

It will be exploratory in terms of finding out the extent of awareness in environmental responsibilities in the JordanianPharmaceutical industries. Moreover, to identify how the Pharmaceutical industries in Jordan are applicable to the environmental accounting policy in their industries by applying Saymeh and Al Shoubaki (2013) questions to attain these objectives.

Alongside, the study carried out content analysis to fulfil the last objective of the study, in this aspect of determining the level of environmental accounting disclosure in the Jordanian Pharmaceutical Industries. Therefore, the current study depends on two main methods of primary data collection, namely; questionnaire and content analysis method, as both of them are applicable to the objectives which the research aims to achieve and they complement and consolidate each other 12 questionnaires were returned from the 18 questionnaires distributed and 10 valid questionnaires were able to be analysed giving a $62 \%$ response rate.

\section{Research Finding}

These descriptive results attempt to accomplish the study objectives. The first section of findings were based on analyzing the questionnaires and the second section based on analyzing the content analysis which was gathered from the annual reports in order to find out the level of disclosure of environmental accounting in their financial statements. 


\section{Section one: Descriptive Results}

\subsection{Accounting Information System}

The first question was asked in order to identify the availability of accounting information system. The following Table 1 indicates that the awareness of accounting departments is in need of accounting information system in their industry and it indicate the high technology applied in accounting departments as all of them utilize accounting systems.

Table 1. Accounting information system

\begin{tabular}{llc}
\hline Have accounting information system & Frequency & Percentage \\
\hline Yes & 10 & $100 \%$ \\
No & 0 & 0 \\
Not Response & - & - \\
\hline
\end{tabular}

\subsection{An Environmental Information System (EIS)}

Respondents were asked to determine the usage of an environmental information system (EIS), Table 2 below indicates the distribution of the sample by having an environmental information system (EIS) in the company . The table shows that $(60 \%)$ of the study sample has this system while $(40 \%)$ do not have it. This advocates the demand for including environmental accounting in their systems.

Table 2. Environmental information system (EIS)

\begin{tabular}{lll}
\hline Have an environmental information system (EIS) & Frequency & Percentage \\
\hline Yes & 3 & $60 \%$ \\
No & 4 & $40 \%$ \\
An EIS is under development. & 2 & - \\
My organization plans to develop an EIS in the future & 1 & \\
Total & 10 & $100 \%$ \\
\hline
\end{tabular}

\subsection{The Causes of Measurement of Environmental Impact of Organization Activities}

In order to determine the extent of measurement of the environmental impact on industry activities and the reason behind the measurement, respondents were asked to give reasons behind the measurement of the environmental impact. Table 3 below shows the distribution of why industries measure the environmental affects of its activities. The table shows that $(60 \%)$ of the study, samples said, "to the extent needed by the management of the organization", $(20 \%)$ "to the extent required by mandatory requirements" and $(20 \%)$ " to the extent that would allow the organization to disclose environmental information". This shows that organizations make it to the extent needed by the management more than other reasons.

Table 3. The causes of measurement of environmental impact

\begin{tabular}{lll}
\hline The causes of measurement of environmental impact & Frequency & Percentage \\
\hline To the extent needed by the management of the organization & 6 & $60 \%$ \\
To the extent required by mandatory requirements & 2 & $20 \%$ \\
To the extent that would allow the organization to disclose environmental & 2 & $20 \%$ \\
information & & $100 \%$ \\
Total & 10 & $100 \%$ \\
\hline
\end{tabular}

\subsection{Commitment of the Jordanian Pharmaceutical Industries' to Environmental Accounting Standards}

In order to achieve the study objectives which concern the identification of the level of Commitment of Jordanian Pharmaceutical industries' to environmental accounting standards. The respondents were ranked to the level of commitment in terms of the reasons behind the commitments shown in Table 4 below. The Response trends were positive about all the paragraphs, the arithmetic mean is higher than the standard mean (3), and the results revealed in the table that the internal policies and governmental regulations in the Jordanian 
Pharmaceutical industries were represented by a commitment Jordanian Environment Protection Act No. 52 of 2006. As a result the study indicates that the Jordanian Pharmaceutical industries committed to the environmental accounting by both the internal policies and governmental law.

Table 4. The Commitment of the Jordanian Pharmaceutical industries' to environmental accounting standards

\begin{tabular}{lll}
\hline $\begin{array}{l}\text { Commitment of the Jordanian Pharmaceutical industries companies' to environmental } \\
\text { accounting standards. }\end{array}$ & Sean Deviation \\
\hline $\begin{array}{l}\text { There are internal laws and regulations in the Jordanian Pharmaceutical industries to } \\
\text { ensure the preservation of the environment and dealing with it. }\end{array}$ & 4.033 \\
$\begin{array}{l}\text { The company thing takes into account the social responsibility when it sets the human } \\
\text { resources }\end{array}$ & 3.866 & 0.927 \\
$\begin{array}{l}\text { Keep pace with developments in Jordanian Pharmaceutical industries that arise on the } \\
\text { laws and regulations related to environmental responsibility }\end{array}$ & 3.633 \\
$\begin{array}{l}\text { There is interest among decision makers certain concern about environment and the } \\
\text { natural resources in general }\end{array}$ & 3.633 & 0.950 \\
$\begin{array}{l}\text { There is a formal follow-up by the environmental authorities of the Jordanian } \\
\text { Pharmaceutical industries }\end{array}$ & 3.566 & 0.935 \\
There is commitment to environmental and social responsibilities which are not imposed \\
by laws
\end{tabular}

\subsection{Requirements to Keep Pace with Development Developments through Environmental Accounting Function}

As shown in table 5, respondents were asked their view of requirements regarding in keeping up with the developments through the accounting function of environmental trends were positive about all the paragraphs as the average arithmetic is higher than the standard mean (3). Accordingly, the study revealed the availability of electronic accounting system, internal environmental control units, and educational programs and courses are main essential requirements to keep pace with the development of the environmental accounting functions.

Moreover, the respondents indicate the difficulties in terms of measuring environmental costs based on the information provided via environmental information systems and indicate the low disclosure of their environmental performance via online networks.

Table 5. Commitment of the Jordanian Pharmaceutical industries' to environmental accounting standards

\begin{tabular}{|c|c|c|}
\hline $\begin{array}{l}\text { Requirements to keep pace with developments through environmental accounting } \\
\text { function }\end{array}$ & Mean & St. Deviation \\
\hline $\begin{array}{l}\text { Availability of electronic accounting system to fulfill the purposes of Jordanian } \\
\text { Pharmaceutical industries requirements of disclosure of environmental } \\
\text { performance }\end{array}$ & 3.633 & 1.033 \\
\hline $\begin{array}{l}\text { There is an electronic system that provides the administration with financial lists } \\
\text { related to environmental accounting }\end{array}$ & 3.566 & 1.278 \\
\hline $\begin{array}{l}\text { There are internal environmental control units to provide Jordanian } \\
\text { Pharmaceutical industries decision makers with information }\end{array}$ & 3.466 & 1.105 \\
\hline $\begin{array}{l}\text { There are educational programs and courses held by Jordanian industrial } \\
\text { companies to know the disclosure requirements of environmental performance }\end{array}$ & 3.333 & 0.958 \\
\hline $\begin{array}{l}\text { companies are facing difficulties in measuring environmental costs based on the } \\
\text { information provided via the environmental information systems }\end{array}$ & 3.133 & 0.973 \\
\hline Companies disclose their environmental performance via online networks & 2.766 & 1.006 \\
\hline
\end{tabular}

\subsection{Efficiency and Effectiveness of the Organization Activities through Environmental Accounting}

The respondents ranked their view on achieving efficiency and effectiveness in the work through environmental accounting in terms of the importance as shown in Table 6 below.

The results revealed that Jordanian Pharmaceutical industries were concerned in the disposal of industrial waste that distinguished them from others with mean (4.1) with a standard deviation (0.922), and they take into account 
environmental costs when they calculated the production costs with mean (4.) with a standard deviation (0.830). Furthermore, the administrations are concerned with environmental responsibilities when determining prices and measuring the feedback from their customers regarding the importance of environmental responsibilities.

Table 6. Efficiency and effectiveness of the organization activities through environmental accounting

\begin{tabular}{|c|c|c|}
\hline Efficiency and effectiveness of the organization activities through environmental accounting. & Mean & $\begin{array}{l}\text { St. } \\
\text { Deviation }\end{array}$ \\
\hline $\begin{array}{l}\text { Jordanian Pharmaceutical industries are concerned in disposal of industrial waste that distinguishes them from } \\
\text { others. }\end{array}$ & 4.100 & 0.922 \\
\hline Environmental costs are taken into account when calculating production costs & 4.000 & 0.830 \\
\hline Administrations are concerned with environmental responsibility when determining prices. & 3.900 & 0.994 \\
\hline $\begin{array}{l}\text { Companies' administrations are interest by the adequacy of lighting and colors in the production sites which helps to } \\
\text { maintain the performance and stability of their staff. }\end{array}$ & 3.566 & 1.304 \\
\hline There are feedbacks from customers reveal the importance of caring to environmental responsibilities & 3.533 & 1.074 \\
\hline $\begin{array}{l}\text { Companies are concerned about environmental responsibility by allocating a portion of their profits as donations to } \\
\text { environmental associations. }\end{array}$ & 3.500 & 1.074 \\
\hline Companies care about special needs individuals and identify aspects of care about them. & 3.200 & 1.095 \\
\hline
\end{tabular}

\section{Section Two: Content Analysis}

This section aimed to identify the level of disclosure of environmental accounting in the Jordanian Pharmaceutical industries by examining the annual report for each company separately as shown in table 8 below. Accordingly, the study indicates that the majority of the Jordanian Pharmaceutical industries disclose their environmental accounting information in their financial statements which reflects the high level of awareness of the importance of the environmental accounting which support the above findings in the first section.

Table 7. Environmental accounting disclosure

\begin{tabular}{|c|c|c|c|c|}
\hline \multirow[t]{2}{*}{ Environmental information } & \multicolumn{2}{|c|}{ No disclosure } & \multicolumn{2}{|c|}{ Fully disclosure } \\
\hline & Frequency & Percentage & Frequency & Percentage \\
\hline Employee Training & 2 & $20 \%$ & 8 & $80 \%$ \\
\hline Distribution of Employees & 2 & $20 \%$ & 8 & $80 \%$ \\
\hline Environmental Policies & 2 & $20 \%$ & 8 & $80 \%$ \\
\hline Environmental Performance & 2 & $20 \%$ & 8 & $80 \%$ \\
\hline Environmental Protection & 2 & $20 \%$ & 8 & $80 \%$ \\
\hline Social Community Programs & 2 & $20 \%$ & 8 & $80 \%$ \\
\hline Social Policies-Customer Health & 2 & $20 \%$ & 8 & $80 \%$ \\
\hline
\end{tabular}

\section{Conclusion}

The study has investigated the environmental accounting in the Jordanian context; particularly the Jordanian Pharmaceutical industries from multiple aspects. Mainly: identifying the extent of awareness on environmental responsibilities in the Jordanian Pharmaceutical industries; identifying how the Pharmaceutical industries in Jordan apply the environmental accounting policy in their factories; assessing the efficiency and effectiveness of environmental accounting functions in industrial companies by comparing the actual procedures applied with Jordanian Environmental Protection Act No. 52 of 2006; and finally, determine the level of environmental accounting disclosure in the Jordanian Pharmaceutical industries.In order to maximize the validity and reliability of the research findings, the research utilized two methods (questionnaire, and content analysis method).

Therefore, 10 valid questionnaires gave a $62 \%$ response rate, the research findings that were discussed in the earlier section, the findings reported that the Jordanian Pharmaceutical industries utilized high technology in accounting departments, $60 \%$ of them utilized environmental information system (EIS) in the company. The need by management of the organization was the main cause of measurement of environmental impact of their activities followed by obligatory causes mainly the Jordanian Environment Protection Act No. 52 of 2006. In the same aspect the study revealed that the Jordanian Pharmaceutical industries committed to Environment accounting by both internal policies and governmental regulations. 
The study indicated that the availability of electronic accounting system, an electronic system, an internal environmental control units, and educational programs and courses are main essential requirements to keep pace with the development of environmental accounting functions.

Furthermore, the study indicated that Jordanian Pharmaceutical industries were concerned in the disposal of industrial waste which distinguishes them from others as efficiency and effectiveness of the organization activities through environmental accounting, alongside with calculating production costs and determining prices.

Finally, the study revealed that that the majority of the Jordanian Pharmaceutical industries disclose their environmental accounting information in their financial statements.

\section{Recommendations and Future Research}

based on the research findings and conclusion, the research has produced some recommendations to the Jordanian Pharmaceutical industries in order to boost the environment accounting role of firms in that sector, namely: taking into account the commitment of the Jordanian Environment Protection Act No. 52 of 2006; there is a need of awareness of the framework and the general concepts of environmental accounting and its applicable methods, and accounting systems; keeping up with the developments that arise from the laws and regulations related to environmental responsibility; and finally, need to follow the responsibilities which might not be imposed by environmental laws, besides the need to set up a criteria to guide accountants in the practice of environmental accounting. The current study examines environmental accounting in the Jordanian Pharmaceutical industries sector, Consequently, it would be useful to conduct further research related to environmental accounting for other sectors.

\section{Acknowledgement}

The Author is grateful to the Applied Science Private University, Amman, Jordan, for the full financial support granted to this research project ( Grant No. DRGS-2014-2015-63).

\section{References}

Abdul, A., Saymeh, F., \& Younes, A. S. (2013). The commitment of The Jordanian Industrial Companies in Applying Environmental Accounting. European Journal of Business and Management, 5(16).

ACCA. (2003). The Big Picture: How the Environment Influences Corporate Profit. London: The Association of Chartered Certified Accountants.

Adams, C. A., Hill, W. Y., \& Roberts, C. B. (1998). Corporate Social Reporting Practices in Western Europe: Legitimating Corporate Behaviour? The British Accounting Review, 30(1), 1-21. http://dx.doi.org/10.1006/bare.1997.0060

Baba, M. C. (2012). Advantages of Implementing Environmental Accounting Within An Economic Entity. Anale. SeriaŞtiințeEconomice. Timişoara, (XVIII/2), 15-24.

Bansal, P., \& Howard, E. (1997). Business and the Natural Environment. Oxford, Boston: Butterworth-Heinemann, p. 278.

Boyd, J. W. (1998). The Benefits of Improved Environmental Accounting: An Economic Framework to Identify Priorities. Resources for the Future, Discussion Paper 98-49 [September] 1998, Washington, DC. Retrieved from http://www.rff.org./Boyd.cfm

Charles, H. C., \& Dennis, M. P. (2013). Green accounting: Reflections from a CSR and environmental disclosure $\begin{array}{lllll}\text { perspective. Critical Perspectives on } & \text { 443-447. }\end{array}$ http://dx.doi.org/10.1016/j.cpa.2013.04.003

Cho, C., \& Roberts, R. (2010). Environmental reporting on the internet by America's Toxic 100: Legitimacy and self-presentation. International Journal of Accounting Information Systems, 11, 1-16. http://dx.doi.org/10.1016/j.accinf.2009.12.003

Christine, J. (2003). The use of Environmental Management Accounting (EMA) for identifying environmental costs. Journal of Cleaner Production, 11(6), 667-676. http://dx.doi.org/10.1016/S0959-6526(02)00107-5

Deegan, C., Rankin, M., \& Voght, P. (2000). Firms' Disclosure Reactions to Major Social Incidents: Australian Evidence. Accounting Forum, 24(1), 101-130. http://dx.doi.org/10.1111/1467-6303.00031

Ditz, D., \& Ranganathan, J. (1997). Measuring Up: Toward a Common Framework for Tracking Corporate Environmental Performance. Washington, D.C.: World Resources Institute, p. 40.

Frost, G. R., \& Wilmshurst, T. D. (2000). The Adoption of Environment-Related Management Accounting: An 
Analysis of Corporate Environmental Sensitivity. Accounting Forum, 24(4), 344-365. http://dx.doi.org/10.1111/1467-6303.00045

Gamble, G. O., Hsu, K., Jackson, C., \& Tollerson, C. D. (1996). Environmental Disclosures in Annual Reports: An International Perspective. The International Journal of Accounting, 31(3), 293-331. http://dx.doi.org/10.1016/S0020-7063(96)90022-9

Gray, R., \& Bebbington, J. (2001). Accounting for the Environment (2nd ed.). London: SAGE Publications.

Massimo, C., \& John, B. (2013). Social and environmental accounting, organizational change and management accounting: A processual view. Management Accounting Research, 24(4), 349-365. http://dx.doi.org/10.1016/j.mar.2013.10.004

Michael, J. J. (2011). The nature, use and impression management of graphs in social and environmental accounting. Accounting Forum, 35(2), 75-89. http://dx.doi.org/10.1016/j.accfor.2011.03.002

Nasir, Z. Q., Dhiresh, K., \& Surya, B. T. (2012). Environmental Accounting and Reporting: an Essential Component of Business Strategy. Asian Journal of Research in Banking and Finance, 2(4).

Papaspyropoulos, K. G., Blioumis, V., Christodoulou, A. S., Birtsas, P. K., \& Skordas, K. E. (2012). Challenges in implementing environmental management accounting tools: The case of nonprofit forestry organization. Journal of Cleaner Production, 29-30.

Patten, D. (2002). The Relation Between Environmental Performance and Environmental.

Roger, L. B., \& Chika, S. (2006). Environmental management accounting applications and eco-efficiency: case studies from Japan. Journal of Cleaner Production, 14(14), 1262-1275. http://dx.doi.org/10.1016/j.jclepro.2005.08.012

Saunders, M. (2007). Research methods for business students (4th ed.). Harlow: Financial Times Prentice Hall.

Teerooven, S., \& Collins, G. N. (2013). Social and environmental accounting as symbolic and substantive means of legitimation: The case of HIV/AIDS reporting in South Africa. Accounting Forum, 37(2), 92-109. http://dx.doi.org/10.1016/j.accfor.2013.04.002

Vivien, B. (2014). Accounting narratives and the narrative turn in accounting research: Issues, theory, methodology, methods and a research framework. The British Accounting Review, 46(2), 111-134. http://dx.doi.org/10.1016/j.bar.2014.05.001

\section{Copyrights}

Copyright for this article is retained by the author(s), with first publication rights granted to the journal.

This is an open-access article distributed under the terms and conditions of the Creative Commons Attribution license (http://creativecommons.org/licenses/by/3.0/). 